DOI https://doi.org/10.36059/978-966-397-226-8-2

\title{
MODERN FORMS OF FOREIGN LANGUAGE REMOTE TEACHING: SYNCHRONOUS, ASYNCHRONOUS AND BLENDED
}

\section{Irchyshyna M. V.}

\section{INTRODUCTION}

One of the most pressing, hotly debated and painful issues for education at the moment is the organization of remote education for undergraduates in connection with the COVID-19 pandemic. Although the latest technologies have been more or less successfully implemented in the teaching process in all higher education institutions of our country, at every step both academic staff members and undergraduates face and seek solutions to problems of different nature and character. Despite the existing scientific research on the psychological and pedagogical, didactic, methodological and organizational features of remote learning, the final generalized result, which would more or less equally take into account all wishes and would not be stressful for both sides of the educational process, has not been created so far.

The concept of "remote teaching" can be interpreted in various ways. For instance, according to official information presented on the website of the Ministry of Education and Science of Ukraine it is: "an opportunity to study and obtain the necessary knowledge remotely at any convenient time ${ }^{48,}$, as well as in accordance with the Regulations on remote teaching: "individualized process of acquiring knowledge, skills, abilities and ways of human cognitive activity, which occurs mainly through the indirect interaction of distant participants of the educational process in a specialized environment that operates on the basis of modern

${ }^{48}$ Офіційний сайт Міністерства освіти та науки України URL: https://mon.gov.ua/ua/osvita/visha-osvita/distancijna-osvita. 
psychological and pedagogical and information and communication technologies 49 ",

According to the research by V.I. Ovsiannikov, which provides a thorough analysis of the term "remote teaching", in modern theory and practice the term "remote education" is often used as a synonym: "Remote education is remote teaching. Teaching is realized through a combination of mail, radio, television, electronic communications, telephone and newspapers with limited direct contact of the undergraduate with the academic staff members or with his full absence". It is also noticed that remote teaching can be described as "a planned teaching process that uses a wide range of technologies to communicate with the undergraduates remotely in order to interact with them and assess the knowledge they have acquired ${ }^{50 \text { ". }}$

O. O. Andreiev and V. I. Soldatkin state that remote teaching is a new way of educational process organization, which is based on the principle of independent undergraduate learning. The learning environment in this case is characterized by the fact that undergraduates are mostly distant from the academic staff members in space and/or time. At the same time, they have the opportunity to establish and maintain a dialogue through telecommunications at any time. O. O. Andreiev and V. I. Soldatkin also define remote teaching as "a set of information technologies that provide undergraduates with the bulk of the research material, interactive cooperation of those who teach and those who are being taught, in the educational process, giving undergraduates the opportunity to work independently to master the material, as well as assessment of their knowledge and skills acquired in the learning process". According to the authors, remote learning is a new stage of remote learning, which

\footnotetext{
${ }^{49}$ Положення про дистанційне навчання. Наказ міністерства освіти і науки Украйни від 25.04.2013 № 466. Зареєстровано в Міністерстві юстиції України 30 квітня 2013 р. за № 703/23235. URL: https://zakon.rada.gov.ua/laws/show/z0703-13\#n18.

${ }^{50}$ Овсянников В. И. Вопросы организации обучения без отрыва от основной деятельности (дистанционного образования). - М. : Изд-во МГОПУ. 1999. URL: http://pidruchniki.com/ 1209061355085/pedagogika/osoblivosti_distantsiynogo_navchannya (дата звернення 04.11.2020).
} 
provides the use of information technology based on the use of personal computers, video and audio equipment ${ }^{51}$.

There is one more rather comprehensive definition by O. O. Andreiev, which takes into account all the features and options for the organization of remote teaching: "Remote teaching is a synthetic, integrated humanistic form of learning, based on the use of a wide range of traditional and modern information technologies and their technical means used for delivery of educational material, its independent study, dialogue exchange between the academic staff members and the undergraduates, and the learning process is generally uncritical about their location in space and time, as well as about a particular educational institution $^{52, " . ~ A c c o r d i n g ~ t o ~ t h i s ~ d e f i n i t i o n, ~ r e m o t e ~ t e a c h i n g ~ a p p e a r s ~ a s ~}$ a special pedagogical technology of the XXI century based on open learning strategy using modern technologies for communication in the informational environment.

All these definitions reflect one or more aspects of a complex and multifaceted phenomenon associated with remote teaching using modern computer technology. However, the success of remote teaching depends on its effective organization, on the management of the process itself, and on the skills of the academic staff members involved. Moreover, it has its own peculiarities and features that allow to significantly expand the types of educational work compared to traditional teaching. That is why there are two main approaches to the way remote teaching can be organized: synchronous and asynchronous remote cooperation.

\section{Asynchronous teaching}

Asynchronous teaching or learning refers to a remote education, when there is no direct contact between the academic staff members and the undergraduates. The process does not take place so quickly, with a slight delay, due to the impossibility of personal presence. But this is a great option for those who do not have the opportunity to travel outside their place of residence and study in close contact with the academic staff

\footnotetext{
${ }^{51}$ Андреев А. А., Солдаткин В. И. (2000). Дистанционное обучение: сущность, технология, организация. М. : Изд-во МЭСИ. 350 с.

${ }^{52}$ Андреев А. А. (1998). Введение в дистанционное обучение. Компьютеры в учебном прочессе. М. : Интерсоциоинформ. № 2. С. 25-68.
} 
member. At the same time, asynchronous education goes even further, based on the sometimes completely independent work of the undergraduate. The academic staff members prepare the materials and training scheme in advance, and the undergraduate assimilates the information in a free online schedule without interactive interaction. The undergraduate sends the completed assignments to the academic staff member, who can check them after a while, that is, the educational process takes place in a delayed format.

According to the definition on the website of the University of Waterloo, asynchronous learning means that the academic staff member and the undergraduates in the course all engage with the course content at different times (and from different locations). The academic staff member provides undergraduates with a sequence of units which they move through as their schedules permit. Each unit might make use of assigned readings or uploaded media, online quizzes, discussion boards, and more. The academic staff member guides the undergraduates, provides them with feedback, and assesses them as needed $^{53}$. Thus, asynchronous learning occurs when undergraduates learn the same thing at different times and from different places.

The main characteristic of asynchronous learning is that it is more or less detached from the usual constraints. That is, it is not dictated by time, place or collaboration between academic staff members and undergraduates. There are always exceptions and variations though. This critical topic of independence is transforming both the teaching and the learning processes.

There are many ways of how asynchronous teaching can be organized, for instance:

1) e-learning - one of the most advanced types of asynchronous learning. Typically, e-learning takes place on the learning platform: instructors upload training courses there, and undergraduates take them each in their own account;

\footnotetext{
${ }^{53}$ Synchronous and asynchronous online learning. University of Waterloo official website. URL: https://uwaterloo.ca/keep-learning/strategies-remote-teaching/synchronous-vsasynchronous-online-learning.
} 
2) a mailing list course - is a chain of emails about a specific learning topic, where each letter is a lesson, and together they add up to a complete programme. It is possible to send targeted questions, answers or approvals to anyone involved in the learning process by email. However, more and more spam filters block emails, thereby disrupting the dialogue and making it unreliable. This type of communication is only suitable for personal "targeted" communication, making public discussions difficult. Moreover, it can be extremely inconvenient to accumulate materials in the form of e-mails, as well as to store them for a long time;

3) videos (YouTube etc);

4) wikies (a relatively new and popular way to exchange information. It is a website that can be shared by any learner, with the ability to editing and entering new data. Group participation in the creation of the material makes the process interesting, involving undergraduates in the formation of the knowledge base. Editing is not only a wiki's strength, but also a weakness. Ability to change the content and add other data can lead to negative consequences. Therefore, it is necessary to limit rights and constant monitoring);

5) online textbooks and e-books;

6) articles and blogs;

7) interactive presentations;

8) web-sites and forums;

9) tests, tasks and exercises.

Asynchronous teaching and learning have a number of advantages, like:

- flexibility of the schedule - the undergraduates himself chooses the mode of mastering knowledge that is convenient for him. Undergraduates can access the course content, and initiate or respond to interactions with the instructor and their peers, when it best suits their schedule. Allows undergraduates to work around unanticipated challenges such as falling sick for a week, or dealing with a family emergency;

- accessibility - you can study new materials from anywhere in the world and 
- individualism - it is not necessary to enroll in a group to complete the required course; the schedule is individual;

- saving money - teaching and learning on online platforms does not always require the undergraduates to have a textbook;

- comprehension-friendliness - recorded sessions allow undergraduates time to digest the session content and/or conduct further research before posing questions in a discussion group. This is better for more deliberate thinkers and also, in some cases, for undergraduates whose first language is not English;

- independence - undergraduates can re-watch recorded sessions to deepen their learning, or to review content prior to a final exam. Undergraduates can likewise review threads in discussion groups long after those discussions have taken place;

- democracy - during a live session, only a small number of undergraduates will be able to ask questions; in an online discussion group all undergraduates can pose questions or make comments.

According to S. Hrastinsky, asynchronous learning provides an impetus for the development of professional and personal qualities in a person, which will definitely be useful in the future. Having the opportunity to discuss their ideas within the framework of the studied program, undergraduates actively interact with other participants, they learn to present information and develop it further. The researchers argue that asynchrony helps to increase the level of motivation in a person, which, in turn, contributes to a deeper and faster memorization of information. Working on assignments online, undergraduates have a lot of time to process knowledge, think about solutions. The resulting interaction with other undergraduates develops their cognitive skills, communication skills, and activates thinking ${ }^{54}$.

Obviously, there are also some disadvantages, for example:

- lack of teacher's attention: undergraduates might feel less connected to an instructor when they are watching a recorded session;

- lack of peer communication: undergraduates might feel less connected to the course overall when they do not see their classmates;

\footnotetext{
${ }^{54}$ Hrastinski, S. Asynchronous and Synchronous E-Learning. URL: http://net.educause.edu/ir/ library/pdf/EQM0848.pdf
} 
- procrastination: undergraduates might put off engaging with a recorded session because they can always "do it later";

- lack of involvement: asynchronous learning requires significant task initiation skills since none of the class time is scheduled, only the assessment deadlines;

- lack of enthusiasm: asynchronous learning requires a higher level of commitment and independent learning skills. For the most successful result, undergraduates need to have a high degree of responsibility and to be able to motivate themselves to study new material, follow the schedule and engage in self-control;

- lack of universality - not everyone who wants to learn for example the English language can be satisfied with the conditions of asynchronous education, not all programs and knowledge bases are created for this.

It becomes clear that this format of education has its own characteristics, which may not be suitable for everyone. It is worth understanding when such training can be fruitful,

- if you need to prepare for the exam in a short time, as this format will help to achieve maximum performance in the test format;

- if it is necessary to memorize a lot of theoretical knowledge, the undergraduate has the opportunity to repeat the material as long as it takes to fully memorize it;

- if it is necessary to teach the maximum number of undergraduates with different levels of training, there is no need to create a group for this and teach everyone at once, each undergraduate receives his own material, which is convenient for both themselves and the academic staff member.

However, asynchronous teaching cannot achieve its goal completely if the passage of practical material is needed, where the interaction of the undergraduate and the academic staff member is important. It can be quite chellenging to learn, for example, singing, driving a car or playing a musical instrument remotely; or if visual examples and live communication with the curator are essential to memorize information. This often happens when studying foreign languages, when a dialogue with an academic staff member or with a direct native speaker is 
required. In these cases, usually asynchronous learning is complemented by online conversations, necessary materials for oral study.

The rapid spread of modern computer telecommunications puts on the agenda a number of philosophical, political and social issues related to this phenomenon. At the present the Internet tends to be not just a system of storing and transmitting large amounts of information but becomes a new psychological environment and sphere of human life. Users of computer networks have a number of psychological innovations (interests, motives, needs, attitudes, forms of psychological and social activity), directly related to this new space.

\section{Synchronous teaching}

Synchronous teaching is a method of e-training which is conducted in real time. The academic staff members and the undergraduates engage with the course content and each other at the same time, but sometimes from different locations. The synchronous format is more familiar and understandable for most representatives of the generation born before the digital age, or for those who are poorly versed in new technologies. In addition, people with a predominance of extroverted traits prefer the synchronous format.

To organize such training various tools can be used in real time. The most widely-used are:

1. Live text conferences (chats). The most common communication options are face-to-face chats between two participants in the learning process. However, if necessary, the chat can be public with 3 or more participants in the remote learning process. The disadvantages include the lack of visual contact, and on the part of the academic staff member, the inability to check with whom he/she really communicates. This is especially important when testing knowledge, for example, when conducting remote exams or seminars 55 .

2. Voice and video conferences. Communication takes place in direct contact with the academic staff member and undergraduates via such team-oriented tools like Skype, Zoom, Microsoft Teams

\footnotetext{
${ }^{55}$ Mardarovsky D. Асинхронное и синхронное обучение: что выбрать? URL: https://el-blog.ru/sync-async-learn/
} 
and Google Meet and many others for videoconferencing, along with other multiuser platforms like Dropbox, Google Drive or Microsoft OneDrive. With video communication, the line between face-to-face communication and remote teaching is blurred. In fact, this method of acquiring knowledge combines all the positive qualities of classical fulltime education and remote teaching.

3. Virtual reality conferences (VR). The prospects for remote learning are such that, according to some forecasts, they will soon move to virtual reality. While many organizations shy away from introducing information technology into their work system, some large companies are beginning to introduce VR into their work schedule and get impressive results in this regard. The widespread distribution of VR, of course, should not be expected so far due to the expensiveness of the technology, but in the future this method can be gain popularity ${ }^{56}$.

Therefore, the advantages of the synchronous format are as follows:

- Live communication. Undergraduates can ask questions and get answers in real-time, as the session is proceeding.

- Flexibility of presentation. The academic staff member can gauge the undergraduates understanding in real-time, and adjust the session accordingly.

- Presence effect. Undergraduates feel an increased sense of the academic staff member actually "being there".

- Real-time workshops. Academic staff members can facilitate workshop-style classes and run breakout group activities.

- Peer-to-peer live chats. Real-time interaction can liven up the lesson and make undergraduates feel engaged.

- Strict schedule. Synchronous sessions provide a schedule to help undergraduates who struggle with task initiation to stay on track.

Nevertheless, there are some drawbacks, such as technical problems or not having the necessary equipment or being in different time zones, or inability to take part into the educational process due to health problems or family emergencies. In addition, for some undergraduates and academic staff members it might be uncomfortable to work from

\footnotetext{
${ }^{56}$ Accent Language Center. Асинхронное обучение. URL: https://accent-center.ru/ru/ articles/asinhronnoe-obuchenie.html.
} 
home. What is more, conducting lectures online can be more difficult than sticking to asynchronous style. However, the working day of the synchronous-style academic staff member has its strict limits while the asynchronous one tends to be available all the time. This can lead to quite an exhausting daily routine for academic staff members.

\section{Blended remote teaching}

The search for schemes where the way the educational process is organized with all the advantages of synchronous and asynchronous remote teaching strategies led to the idea of blended remote teaching - an educational process in which these strategies are combined. Thus, educational process is built on the interaction of the undergraduate not only with a computer, but also with an active academic staff member, and the independently studied material can be analyzed, summarized and used to solve assigned tasks.

However, even this approach can also be rather debatable. In the article "The Difference Between Emergency Remote Teaching and Online Learning" published on EDUCAUSE by C. Hodges, S. Moore, B. Lockee, T. Trust and A. Bond, the authors mention that the idea of blended learning was drawn into political agendas without paying sufficient attention to the fact that institutions would make different decisions and invest differently, resulting in widely varying solutions and results from one institution to another ${ }^{57}$.

In higher education, blended teaching is used very actively at universities in the USA and Europe. In 2007 about $55 \%$ percent of US universities used blended teaching in the educational process. According to forecasts analysts, this figure will gradually grow and increase to $80 \%$. The USA is the leader in the use of blended teaching ${ }^{58}$.

Initially, the idea of blended teaching was to provide the undergraduates with the opportunity to choose the most convenient organizational form of training. But in fact, blended learning is almost always established by the university, and the undergraduate is given

\footnotetext{
${ }^{57}$ Hodges C., Moore S., Lockee B., Trust T., Bond A. (2020). URL: https://er.educause.edu/ articles/2020/3/the-difference-between-emergency-remote-teaching-and-online-learning.

${ }^{58}$ Accent Language Center. Асинхронное обучение. URL: https://accent-center.ru/ ru/articles/asinhronnoe-obuchenie.html.
} 
freedom only within this model. In addition, it turns out to be difficult to implement an individual approach to the choice of the studied content. The schedule of the educational process is also is the same for everyone and, as a rule, covers the entire duration of the academic term. In other words, there is no real freedom of choice in existing in blended learning models.

Nowadays, the effectiveness of mastering the course is directly related to the correct choice of the forms (synchronous - asynchronous) and the way the lesson is organized. The optimal combination of the methods of teaching is the core of blended teaching technologies. But in any combination of the listed forms, they should form a holistic educational process, assuming that part of the educational and cognitive undergraduates' activities take place under the direct supervision the academic staff member, and part is submitted for independent work with a remote nature of interaction with the teacher ${ }^{59}$.

\section{Emergency remote teaching}

During the previous academic year, many undergraduates and academic staff members colloquially referred to their courses as "online classes". While these courses were being taught online, it is essential to distinguish classes that were deliberately designed to be administered online from courses that suddenly shifted online due to an emergency (like the switch to remote teaching in spring 2020). In many countries remote teaching has become a forced choice which will finish as soon as the lockdown has been cancelled ${ }^{60}$. Thus, the curricula have not been designed to be used during the whole academic year but transferred online from physical classrooms. These hurried moves online by so

\footnotetext{
${ }^{59}$ Стариченко Б. Е. Синхронная и асинхронная организация учебного процесса в вузе на основе информационно-технологической модели обучения. Инновачионные технологии в образовании. URL: file:///D:/\%D0\%9D\%D0\%9E\%D0\%92\%D0\%90\%D0\%AF\%20\%D0\% 9A\%D0\%90\%D0\%A4\%D0\%95\%D0\%94\%D0\%A0\%D0\%90/\%D0\%9F\%D0\%A3\%D0\%91\% D0\%9B\%D0\%98\%D0\%9A\%D0\%90\%D0\%A6\%D0\%98\%D0\%98\%2020-21/sinhronnaya-iasinhronnaya-organizatsiya-uchebnogo-protsessa-v-vuze-na-osnove-informatsionnotehnologicheskoy-modeli-obucheniya.pdf.

${ }^{60}$ Purdue Online Writing Lab. Coollege of Liberal Arts. Purdue University URL: https://owl.purdue.edu/research/owl_conversations/Essays/remote_teaching_a_students_ perspective.html.
} 
many institutions at once could seal the perception of remote teaching as a weak option, when in truth nobody making the transition to remote teaching under these circumstances will truly be designing to take full advantage of the affordances and possibilities of the online format. As a result, remote teaching is frequently considered to be of lower quality than face-to-face teaching, although this is quite acontroversial statement.

In contrast to experiences that are planned from the beginning and designed to be online, emergency remote teaching is a temporary shift of instructional delivery to an alternate delivery mode due to crisis circumstances. It involves the use of fully remote teaching solutions for instruction or education that would otherwise be delivered face-to-face or as blended or hybrid courses and that will return to that format once the crisis or emergency has abated. The primary objective in these circumstances is not to re-create a robust educational ecosystem but rather to provide temporary access to instruction and instructional supports in a manner that is quick to set up and is reliably available during an emergency or crisis. When we understand emergency remote teaching in this manner, we can start to separate it from "remote teaching". There are many examples of other countries responding to school and university closures in a time of crisis by implementing models such as mobile learning, radio, blended learning, or other solutions that are contextually more feasible.

According to EDUCAUSE experts, typical planning, preparation, and development time for a fully online university course is 6-9 months before the course is delivered. Additionally, online courses are normally designed in accordance with theoretical and practical standards for teaching in virtual contexts. By contrast, the short transition timeline for implementing online instruction in spring 2020 made applying of these standards and preparing instructors next to impossible. As a result, logistical and technical problems are inevitable.

Furthermore, the success of remote teaching implementations depends on the academic staff members' level of digital fluency. The EDUCAUSE experts state that academic staff members are usually more comfortable teaching online by the second or third iteration of their online courses. It will be impossible for every academic staff member to 
suddenly become an expert in remote teaching and learning in this current situation, in which lead times range from a single day to a few weeks. Many of the online learning experiences that academic staff members will be able to offer undergraduates will not be fully featured or necessarily well planned, and there is a high probability for suboptimal implementation.

Thus, the campus support teams that are must be available to help faculty members learn about and implement remote teaching will not be able to offer the same level of support to all academic staff members who need it. Faculty support teams play a critical role in the learning experiences of undergraduates by helping academic staff members develop face-to-face or online learning experiences. Current support models might include full-course design support, professional development opportunities, content development, learning management system training and support, and multimedia creation in partnership with faculty experts. Academic staff members who seek support typically have different levels of digital fluency and are often accustomed to oneon-one support when experimenting with online tools. The urgent shift to remote teaching requires that academic staff members take more control of the course design, development, and implementation process. With the expectation of rapid development of remote teaching and learning events and the large number of academic staff members in need of support, faculty development and support teams must find ways to meet the institutional need to provide instructional continuity while helping academic staff members develop skills to work and teach in an online environment. As such, institutions must rethink the way instructional support units do their work, at least during a crisis.

To sum up, the rapid approach necessary for emergency remote teaching may diminish the quality of the courses delivered. A full-course development project can take months when done properly. The need to "just get it online" is in direct contradiction to the time and effort normally dedicated to developing a quality course. Online courses created in this way should not be mistaken for long-term solutions but accepted as a temporary solution to an immediate problem. Especially 
concerning is the degree to which the accessibility of learning materials might not be addressed during emergency remote teaching ${ }^{61}$. This is one of the most important reasons that universal design for learning should be part of all discussions around teaching and learning.

\section{Remote teaching in Ukraine}

Having just several centres, Ukraine has already made the first significant steps in spreading remote teaching. Remote teaching has been designated as a new form of education in the "Law of Ukraine on higher education" and "Concept for the development of remote navigation in Ukraine" and the programme of its development has been approved. It is necessary to carry out a further significant work with the accreditation of distance curricula and the procedure of recognition of diplomas, received after this form of education. The innovations in the field of ICT also faces some challenges like correspondence to the principles of pedagogy, methodology, administrative management and finance, protection of quality of knowledge, rights of intellectual power and aspects.

In the context of such radical changes of higher education, there are some important aspects which must be taken into account:

1. To start with, the development of remote teaching strategies in Ukraine began much later in comparison to countries of Western Europe and was conducted in extremely unfavorable circumstances. For a long time, the strategy of remote teaching development was absent in Ukraine. The level of information discontinuity also played an important role. On the one hand, Ukraine belongs to the group of fifty biggest countries according to number of population and size of territory. However according to the Network Readiness Index 2016, it takes the $64^{\text {th }}$ position out of 139 countries, estimated for this criterion ${ }^{62}$.

2. It is necessary notice that the rate of annual increase in all types of information resources in Ukraine are significantly ahead of the European countries, as there is insufficient saturation of the of the ICT market. For

\footnotetext{
${ }^{61}$ Hodges C., Moore S., Lockee B., Trust T., Bond A. 2020. URL: https://er.educause.edu/ articles/2020/3/the-difference-between-emergency-remote-teaching-and-online-learning.

${ }^{62}$ The Global Information Technology Report (2016). Innovating in the Digital Economy. URL: http://www3.weforum.org/docs/GITR2016/WEF_GITR_Full_Report.pdf.
} 
the last five years the market of ICT has become even more famiiar to Ukraine.

3. Theoretical, practical and social aspects of remote teaching in Ukraine were poorly developed. Some research by Ukrainian scholars P. V. Dmitrenko, V. M. Kukharenko, V. V. Oleinyk, Yu. A. Pasechnik, O. V. Tretiak and many others were published mainly in 1999-2000 and thus did not influence the situation in Ukraine. The same is about some local achievements in the field of remote teaching at various educational institutions and scientific organizations.

International Science and Research Centre of Informational technologies and systems of the National Academy of Sciences and the Ministry of Education we

The International Scientific and Scientific Center for Information Technologies and Systems by (ISSCITC) the National Academy of Sciences and the Ministry of Education and Science is one of the first scientific and educational organizations in Ukraine, which was updated in 1995. Creating and spreading of remote teaching strategies, it combined the advantages given by communication technologies with the correspondent pedagogical methods by establishing of telecommunication didactic laboratory and distributing new remote teaching strategies based on up-to-date ICT. With the establishment of telecommunication didactic laboratories and further research in the framework of this structure, the results of the wide international participation of the leading universities in England, Holland, Norway, France, Mexico etc. The experience of remote teaching courses designing and development made it possible to formulate a number of important issues and realize the problems, which occur in the process of remote teaching implementation ${ }^{63}$.

Currently, one of the most widely-used systems of remote teaching in Ukraine is Moodle (Modular Object-Oriented Dynamic Learning Environment) also referred to as the learning management system(LMS), course management system (CMS), virtual learning environment (VLE) or simply educational platform for, which gives

\footnotetext{
${ }^{63}$ Концепція розвитку технологій дистанційного навчання в Україні. URL: https://buklib.net/books/24385/. 
academic staff members and undergraduates a wide range of tools for computerized teaching, both face-to-face and remote one. Moodle can be used at educational institutions of all levels, in computer classes as well as for the independent work at home. This system provides various remote teaching procedures, which can be both for synchronous and asynchronous, and therefore, blended remote teaching.

Moodle ensures the possibility of installation of teaching materials and provides the means of access to resources and management and guarantees the interaction of participants during the educational process, for instance, Internet conferences, forums, discussions and chats. Using of networking technologies allows the undergraduates to have their own strategy of education and facilitates not only knowledge and skills acquisition, forms of professional behaviour, but also the formation of the certain structure of personal qualities. The research of conditions of professional competence formation of the future specialists showed that by using the curricula which contain remote teaching components encourages undergraduates' personal responsibility ${ }^{64}$.

All in all, although the level of readiness to emergency remote teaching was not as high in Ukraine as in some European countries, scholars and academic staff members managed to urgently adapt to blended remote teaching strategy by using a range of telecommunication technologies, including Moodle.

\section{CONCLUSIONS}

Remote teaching is becoming more and more widely-spread in the world due to the COVID-19 pandemic and other challenges of the modern times. This is both convenient and effective, and also very promising. According to Ambient Insight, the online education market is growing by $5 \%$ every year. Thus, after a couple of years, it will gradually begin to replace offline learning. This is true both for the corporate sphere and for the general education. Also, the results of some studies indicate that digital technologies are becoming more effective in

\footnotetext{
${ }^{64}$ Болюбаш Н. М. (2010). Фактори та умови формування професійної компетентності майбутніх економістів засобами інформаційного середовища Moodle. Інформаиійні технології і засоби навчання. № 3(17). URL: http://www.ime.eduua.net/em17/emg.html.
} 
education than traditional ones. Already today, many educational institutions use interactive tests, videos, games for better assimilation of information.

As it developed, remote teaching involved new means of transmitting information: television, interactive video, Internet, etc. Subsequently, two main approaches to the implementation of remote teaching appeared - asynchronous and synchronous teaching.

The main distinguishing feature of remote teaching from other types of teaching is the versatile use of modern technologies in the educational process. They can help both in providing undergraduates with the necessary materials for learning, or in testing the acquired knowledge, and in communication with the academic staff member. There are many implemented remote education projects, which differ in technology and media - from the use of paper and telephone to the organization of online conferences.

Asynchronous form involves the individual pace of processing of educational material. The technical basis of this approach can be ordinary correspondence, e-mail, television, web-technology. The advantage of this form of organization is the free pace and schedule of training, which gives the necessary flexibility of the curriculum. The responsibility of the quality of education is based mainly on the learner as it depends on his lher motivation, engagement and effort.

Synchronous form, along with the individual pace of processing of educational material, provides synchronous communication between undergraduates and academic staff members. This can be done through interactive television, instant text or voice messaging, video conferencing.

The combination of synchronous and asynchronous forms, which is blended remote teaching, is probably the most successful way of remote teaching as it can give both the required contact and feedback; and give the undergraduates time and flexibility to comprehend the material and deepen their knowledge on their own. Such a method has already been used in American and European universities.

However, it must be taken into account that there is a significant difference between the course designed deliberately as the online course and the existing curricula which have been transferred online. As 
a result, the quality of remote teaching is yet to grow after thorough consideration and implementation of today's remote teaching experience both in Ukraine and in the world.

\section{SUMMARY}

The article deals with the peculiarities of implementation of remote teaching in the modern world. It has been determined that remote teaching has two main forms - synchronous and asynchronous. Synchronous teaching is claimed to be closer to the traditional face-to-face communication as in this case academic staff members and the undergraduates work together according to the schedule. Asynchronous teaching is based on the prepared in advance materials which are given to the undergraduates so that they can work with it whenever it is convenient for them according to their personal schedule. The article emphasizes that both synchronous and asynchronous forms of remote teaching have advantages and disadvantages which can possibly be avoided by using blended remote teaching, that is, a combination of these two forms in order to make the educational process in general and each lesson in particular holistic and integral. The attention is also drawn to the difference between the initially online course and the one which had been converted into such format due to unpredicted circumstances. The peculiarities of Ukrainian remote teaching realia and one of the most widely-spread means of remote teaching resources have also been mentioned.

\section{REFERENCES}

1. Андреев А. А. (1998). Введение в дистанционное обучение. Компьютеры в учебном проиессе. М. : Интерсоциоинформ. № 2. С. 25-68.

2. Андреев А. А., Солдаткин В. И. (2000). Дистанционное обучение: сущность, технология, организация. М. : Изд-во МЭСИ. 350 с.

3. Болюбаш Н. М. (2010). Фактори та умови формування професійної компетентності майбутніх економістів засобами інформаційного середовища Moodle. Інформаційні технології $і$ засоби навчання. № 3(17). URL: http://www.ime.eduua.net/em17/emg.html.

4. Дистанційна освіта. Офіиійний сайт Міністерства освіти та науки Украӥни. URL: https://mon.gov.ua/ua/osvita/visha-osvita/distancijnaosvita. 
5. Концепція розвитку технологій дистанційного навчання в Україні URL: https://buklib.net/books/24385/.

6. Овсянников В. И. (1999). Вопросы организации обучения без отрыва от основной деятельности (дистанционного образования). М. : Изд-во МГОПУ. URL: http://pidruchniki.com/1209061355085/ pedagogika/osoblivosti_distantsiynogo_navchannya.

7. Положення про дистанційне навчання. Наказ міністерства освіти інауки Украӥни від 25.04.2013 № 466. Зареєстровано в Міністерстві юстииії Украӥни 30 квітня 2013 р. за № 703/23235. URL: https://zakon.rada.gov.ua/laws/show/z0703-13\#n18.

8. Стариченко Б. Е. Синхронная и асинхронная организация учебного процесса в вузе на основе информационно-технологической модели обучения. Инновационные технологии в образовании URL: file:///D:/\%D0\%9D\%D0\%9E\%D0\%92\%D0\%90\%D0\%AF\%20\%D0\%9A\% D0\%90\%D0\%A4\%D0\%95\%D0\%94\%D0\%A0\%D0\%90/\%D0\%9F\%D0\%A $3 \% \mathrm{D} 0 \% 91 \% \mathrm{D} 0 \% 9 \mathrm{~B} \% \mathrm{D} 0 \% 98 \% \mathrm{D} 0 \% 9 \mathrm{~A} \% \mathrm{D} 0 \% 90 \% \mathrm{D} 0 \% \mathrm{~A} 6 \% \mathrm{D} 0 \% 98 \% \mathrm{D} 0$ \%98\%2020-21/sinhronnaya-i-asinhronnaya-organizatsiya-uchebnogoprotsessa-v-vuze-na-osnove-informatsionno-tehnologicheskoy-modeliobucheniya.pdf.

9. Accent Language Center. Асинхронное обучение. URL: https://accent-center.ru/ru/articles/asinhronnoe-obuchenie.html.

10. Hodges C., Moore S., Lockee B., Trust T., Bond A. (2020). URL: https://er.educause.edu/articles/2020/3/the-difference-between-emergencyremote-teaching-and-online-learning.

11. Hrastinski, S. Asynchronous and Synchronous E-Learning URL: http://net.educause.edu/ ir/library/pdf/EQM0848.pdf.

12. Mardarovsky D. Асинхронное и синхронное обучение: что выбрать? URL: https://el-blog.ru/sync-async-learn/.

13. Purdue Online Writing Lab. College of Liberal Arts. Purdue University. URL: https://owl.purdue.edu/research/owl_conversations/ Essays/remote_teaching_a_students_perspective.html.

14. Synchronous and asynchronous online learning. University of Waterloo official website. URL: https://uwaterloo.ca/keep-learning/ strategies-remote-teaching/synchronous-vs-asynchronous-online-learning.

15. The Global Information Technology Report. (2016). Innovating in the Digital Economy. URL: http://www3.weforum.org/docs/GITR2016/ WEF_GITR_Full_Report.pdf. 